\title{
Indentification of biomarker parameters of source maturity and depositional environment in cretaceous rocks of Golpayegan area using gas chromatography - mass spectrometry
}

\author{
Dr.GhodratollahMohammadi \\ Exploration Department, Islamic Azad University, South Tehran branch, Tehran, Iran.
}

\begin{abstract}
Recent studies performed on hydrocarbon source rocks of Golpayegan area in the central Iran led to the identification of significant biomarkers. This article is the first report of biomarkers including steranes and triterpanes present in the cretaceous carbonaceous shales from Golpayegan.Data obtained from analysis of saturated - hydrocarbons using gas chromatography - mass spectrometry $(\mathrm{GC}-\mathrm{MS})$ with $\mathrm{m} / \mathrm{z}=191$ and $\mathrm{m} / \mathrm{z}=217$ show that distribution of normal c27, c28 and c29 steranes is in the order of c27>c28<c29 indicating that organic matter was deposited in open marine environment. Pristane and phytane ratio(pr/ph) which is commonly used as an indicator of oxic and anoxic environment ranges from 0.93 to 1.1 suggesting that organic - rich carbonaceous shales were deposited in anoxic and suboxicenviroments. Maturity of these sediment using c29 sterane ratio $20 \mathrm{~s} / 20 \mathrm{~s}+20 \mathrm{r}$ is equivalent to $0.93-0.95 \%$ virinite reflectance indicating that late - mature or final stages of oil generation has surpassed. Bacterial input and bacterial reworking during early diagenesis is inferred from hopane to steraneratio(0.86 to 1.11$)$.

$\mathrm{Ts} /(\mathrm{Ts}+\mathrm{Tm})$ ratio which is lithology and facies dependent and decreases in anoxic carbonate environment ranges from 0.31 to 0.42 . Due to the fact that samples contain considerable amounts of carbonate minerals the above valuses are in an expected range.Moretane to hopane ratios of 0.10 to 0.34 confirm a maturation level of late oil - window. An example of extensive biodegradation is clearly represented by a shaly sample where all normal alkanes $<30$ even isoprenoids have been removed by bacteria in mass chromatograms $(\mathrm{m} / \mathrm{z}=217$ and $\mathrm{m} / \mathrm{z}=191)$ all normal steranes are gone and only hopane occur in minimal concentrations. Finally diasterane/sterane ratio of 1.28 to 1.68 indicate that all reactions responsible for transformation of unstable regular steranes to stable diasteranes have already reached equilibrium.
\end{abstract}

\section{INTRODUCTIONS}

The study area is located in southeast Golpayegan central Iran. The section where the outcrop samples were collected is situated approximately $15 \mathrm{~km}$ east of khansar(Fig.1). According to thicle et al. 1988 narrated by Darvishzadeh 1992 the presence of sandstone and conglomerate layer in the Golpayegan region indicates erosion prior to middle cretaceons. This feature has also been noticed in other parts of central Iran. In some areas volcanic rocks(possibly submarine) which are thought to be associated with the formation of ore bodies in Golpayegan quadrangle underlie the cretaceous. Thiele et al. 1968 stated that the following cretaceous units occur in the Golpayegan region:

A: The basal sandy conglomerate unconformably overlies jurrassic shale and sandstone(only few traces of conglomerate were noticed in the sampled section).

B: In this unit marl and orbitoline - bearing limestone occur alternatively over unit.

C:Orbitoline - bearing limestone shows gray colour and overlies the above marl and limestone unit.

D:Thick marls and blue - gray shalesconformaly lie above orbitolone - bearing limestone. Thin orbitoline bearing limestone layers occur interbedded within the this marls and shales. The above features are almost well noticed in the sampled albian section.

E:The above marls and shales are unconformably overlain by a consistent series of shales and dark slates. These shales change laterally to marly limestone. The age of this unit is reported to be upper cretaceons. This unit with varying thickness is seen in the sampled section(Darvishzadeh 1992). The main objective of this paper is to identy and investigate biomarkers present in organic - rich shales from Golpayegan area. Emphasis is placed on their characteristic features such as biological source input depositional environment and thermal maturity. Biomarkers or biological markers are in fact carbon skeletons present in sediments inherited from living organisms which later have been converted to oil with minor or no change(Waples and Machihara 1991, Peters and Moldowan 1993. 


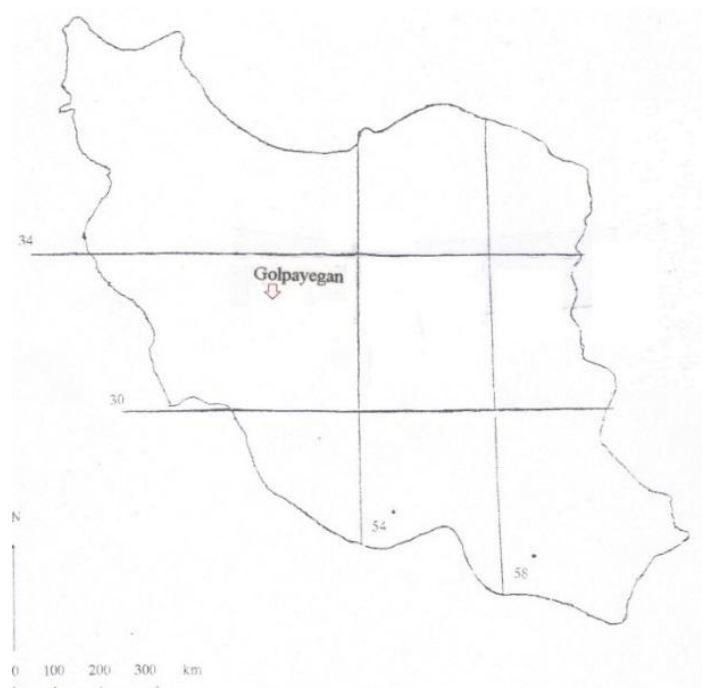

Fig.1 Location of the study area in the central Iran

\section{METHODS}

A total number of 100 outcrop samples from the cretaceous units were selected for organic geochemical studies. Most outcrop samples are exposed to weathering oxidation and bacterial degradation. In order to avoid any kind of contamination unexposed and fresh samples were collected from lower deeper portion of outcrop. The above samples were primarily subjected to macroscopic and microscopic studies then 28 sample were selected for qualitative and quantitative evaluation using rock-eval pyrolysis technique. Subsequently on the basis of their relative organic content and quality 8 samples were selected for soxhlet extraction. Prior to soxhlet extraction the rock samples were crushed and powdered 90 mesh. After placing the powdered samples in thimbles located in soxhlet apparatus the bitumen was extracted using organic solvents such as chloroform and dichloromethane. For further analysis the extracted organic matter(EOM) or bitumen was subjected to deasphaltening and column chromatography. The saturated - hydrocarbon fraction obtained though column chromatography was then analysed using a gas chromatograph(chrompack model cp 9000). Pristine/phytane ratios and concentration of other $n$-alkanes were measured using peak areas. For the purpose of detailed molecular studies including biomarkes suitable samples were selected for gas chromatography - mass spectrometry(GC-MS)analysis. The GC-MS instruments is equipped with a gas chromatograph interfaced with a mass spectrometer which is able to detect different molecular and fragment ions which differ in mass. The complete record of quantities and masses of all ions produced is called its mass spectrum(Fig.2). GC-MS analysis of saturated fraction of bitumen led to the detection of two important group of biomarkers in cludingsteranes $(\mathrm{m} / \mathrm{z}=217)$ and hopanes $(\mathrm{m} / \mathrm{z}=191)$.

Table 1: Geochemical data for the Golpayegan area

\begin{tabular}{|c|c|c|c|c|c|c|c|c|c|}
\hline $\begin{array}{c}\text { Sample } \\
\text { No }\end{array}$ & $\begin{array}{c}\text { Pristine }= \\
\operatorname{Pr}\end{array}$ & $\begin{array}{c}\text { Phytane }= \\
\text { Ph }\end{array}$ & $\mathrm{Pr} / \mathrm{Ph}$ & CPI & $\begin{array}{c}\mathrm{n}- \\
\mathrm{C} 17\end{array}$ & $\begin{array}{c}\mathrm{n}- \\
\mathrm{C} 18\end{array}$ & $\begin{array}{l}\mathrm{Pr} / \mathrm{n}- \\
\mathrm{C} 17\end{array}$ & $\begin{array}{c}\mathrm{Ph} / \mathrm{n}- \\
\mathrm{C} 18\end{array}$ & C27/C29 \\
\hline $\mathrm{C} 1$ & 1.33 & 1.21 & 1.10 & 1.135 & 1.81 & 1.80 & 0.74 & 0.67 & 0.78 \\
\hline $\mathrm{C} 3$ & 1.10 & 1.00 & 1.10 & 0.81 & 1.51 & 1.44 & 0.73 & 0.70 & 0.85 \\
\hline $\mathrm{C} 4$ & 0.99 & 1.07 & 0.93 & 0.95 & 1.60 & 1.57 & 0.62 & 0.68 & 0.92 \\
\hline $\mathrm{C} 7$ & 1.18 & 1.10 & 1.07 & 1.095 & 1.65 & 1.71 & 0.72 & 0.65 & 0.81 \\
\hline $\mathrm{C} 8$ & 0.91 & 0.90 & 1.01 & 0.79 & 1.27 & 1.32 & 0.72 & 0.68 & 0.75 \\
\hline C10 & 0.99 & 0.94 & 1.06 & 1.02 & 1.32 & 1.36 & 0.75 & 0.69 & 0.71 \\
\hline $\mathrm{C} 12$ & 0.07 & 0.07 & 0.99 & 1.00 & 0.29 & 0.20 & 0.25 & 0.46 & $\begin{array}{c}\text { Extensively } \\
\text { biodergredsteranes } \\
\text { completely gone }\end{array}$ \\
\hline
\end{tabular}




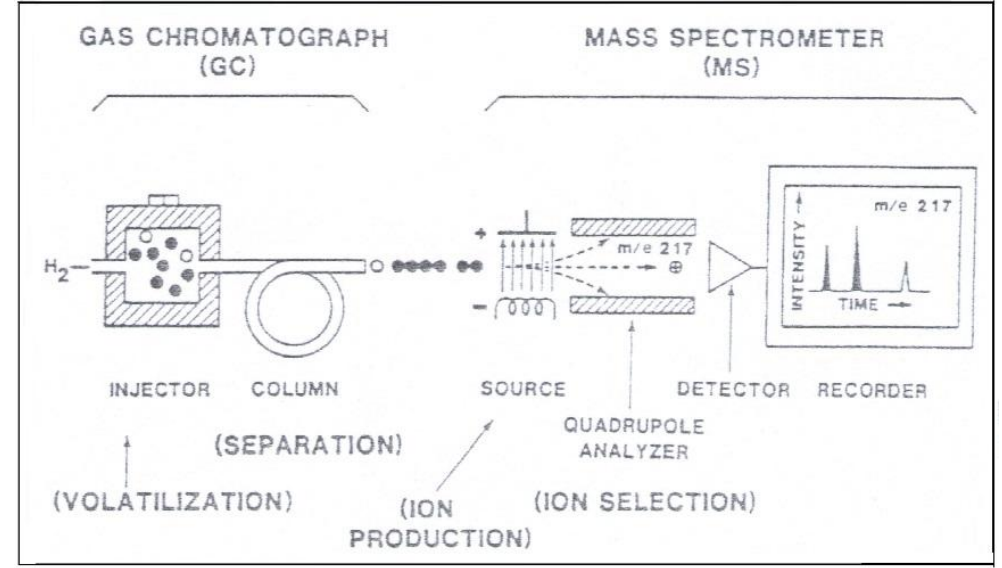

Fig.2 Schematic diagram of a gas chromatography mass spectrometry system(Waples 1991)

III.

\section{DISCUSSION}

Gas chromatograms obtained from analysis of saturated hydrocarbons have pristine/phytaneratios(pr/ph) in the range 0.93 to 1.1 (Table 1). These ratios suggest that organic - rich rocks were deposited under anoxic and suboxicconditions(Fig.3). Pristine(C19) and phytane(C20) are isoprenoids that their origin is attributed to chorophyll and archaeobacteria lipids(Power and McKirdy 1973).

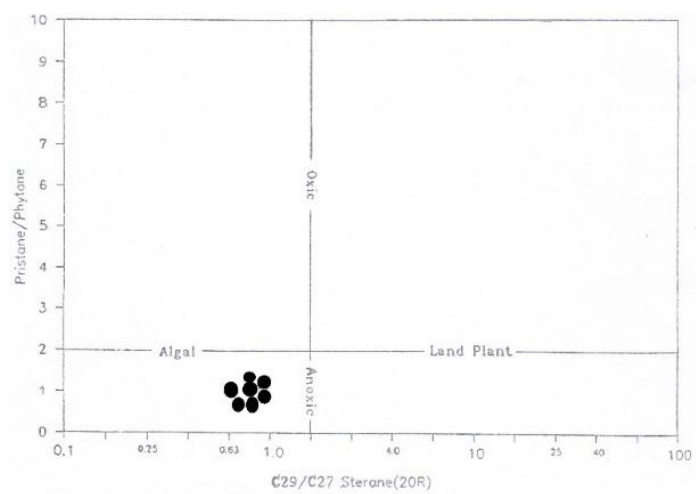

Fig.3 Pristine/phytane versus c29/c27 sterane(2or)(Huang and Meinschein 1976)

Distribution of normal steranes in gas chromatography - mass spectrometry(GC-MS) with $\mathrm{m} / \mathrm{z}=217$ is in the order of c27>c28<c29 idicting that deposition of organic - rich rocks took place in an open marine environment. In order to distinguish sedimentary environment it is customary to use triangular diagram(Fig.4).

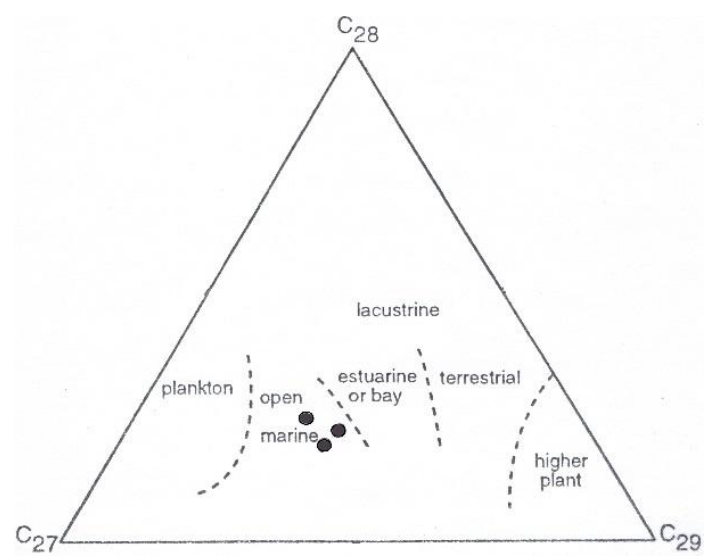

Fig.4 Ternary diagram showing the relative abundances of C27 C28 C29 regular steranes in the saturate fraction of hydrocarbons steranes in the saturates fraction of hydrocarbons determined by GC-MS $(\mathrm{m} / \mathrm{z}=127)$ the proposed initial environment of deposition are shown by dotted lines(adopted from Waples and Machihara 1991) 
For the distribution and abundance of normal steranes c27, c28 and c29. As shown in Fig.4 samples from Golpayegan were formed in an open marine environment. Previous workers such as Grantham 1986, Waples and Machihara 1991, Peters and Moldowan 1993, stated that higher concentrations of c29 steranes in carboniferous and younger sediments are generally attributed to terrestrial plants while higher concentration of c28 and c27 steranes suggest input of organic matter(phytoplankton) from lacustraine and marine environmets, respectively. Fig.3 illustrates the origin of organic matter and depositional environment for the studied samples using pr/ph ratio versus c29/c27 sterane ratio. The same type of environment(anoxic) and precursor organic matter such as algae is clearly inferred from closely - spaced distribution of the studied samples it is worth mentioning that most workers have considered a pr/ph ratio of 1 or $<1$ for anoxic environment but in this diagram Fig.3. Which was proposed by huang and meinschein 1976, anoxic domain is somewhat extended up to $\mathrm{pr} / \mathrm{ph}=2$ rullkotter and marzi 1988 , have used $20 \mathrm{~s} /(20 \mathrm{~s}+20 \mathrm{r})$ ratio in c29 regular steranes as the most reliable and useful biomarker - maturity parameter. This is because coelution of these regular steranes in the mass chromatogram $(\mathrm{m} / \mathrm{z}=217)$ does not interfere with rearranged steranes. It should be noted that aaa 20r sterane is a biogenic epimer and converts to aaa 20s through maturity during catagenesis(Fig.5).
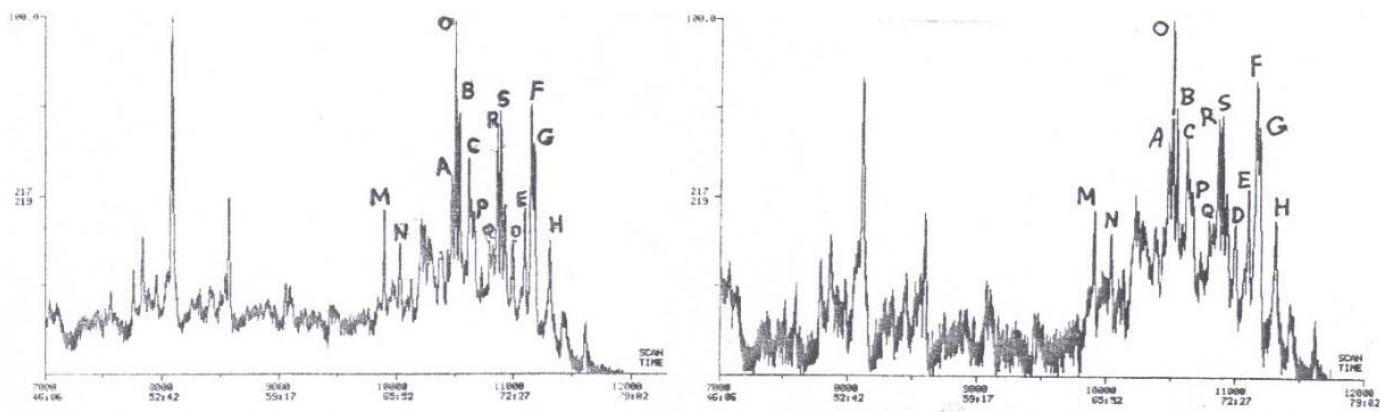

Fig.5 Mass fragment $(\mathrm{m} / \mathrm{z}=217)$ used for identification of specific compounds

As soon as transformation reactions approach equilibrium ratio of $200 \mathrm{or}$ to $20 \mathrm{os}$ remains constant(Fig.5). In this study 20s/(20s+20R) ratio in c29 steranes were measured for each sample. Ratios obtained are equivalent to $0.93-0.95 \%$ vitrinite reflectance indicating that late - mature or final stage of oil generation. Surpassed. Hopane/sterane ratio for the above samples are in the range 0.86 to 1.1(Table 2, Figs 5 and 6). Because hopanes are basically derived from bacteria and cyanobacteria whereas, steranes are dominantly formed from higher plants and algae, this ratio is used to identify precuser organic matter and their environment of deposition. Hopane/sterane ratios of more than unity(Table 2)suggest predominance of bacterial input and bacterial reworking during early diagenesis. Subsequent petrographic investigations performed on kerogen of the same samples clearly confirms intense bacterial reworking which degraded the originalorganic matter into an amorphous material. There is no unique and clear view among researchers with regard to the Ts/(Ts+Tm) ratio. This ratio can be studied and measured in mass chromatogram m/z=191(Fig 6, Table 2). Previous studies suggested that this ratio is just indication of maturation but recent work by peters and Moldowan 1993, have shown that $\mathrm{Ts} /(\mathrm{Ts}+\mathrm{Tm})$ ratio not only depends on maturation but also on factors such as diagenetic condition, lithology, facies. Ts/(Ts+TM) ratio for the Golpayegan samples which contain appreciable amounts of carbonate minerals are in the expected range 0.31 to 0.42 (Table 2 ). Low $\mathrm{Ts}(\mathrm{Ts} / \mathrm{Tm})$ ratio have already been reported frequently from carbonate rocks deposited in an anoxic environment. In certain cases mortane/hopane ratio is used to determine thermal maturity(Table 2). It is often supposed that moretanes are relatively unstable compounds and convert to hopanes with increasing maturity.
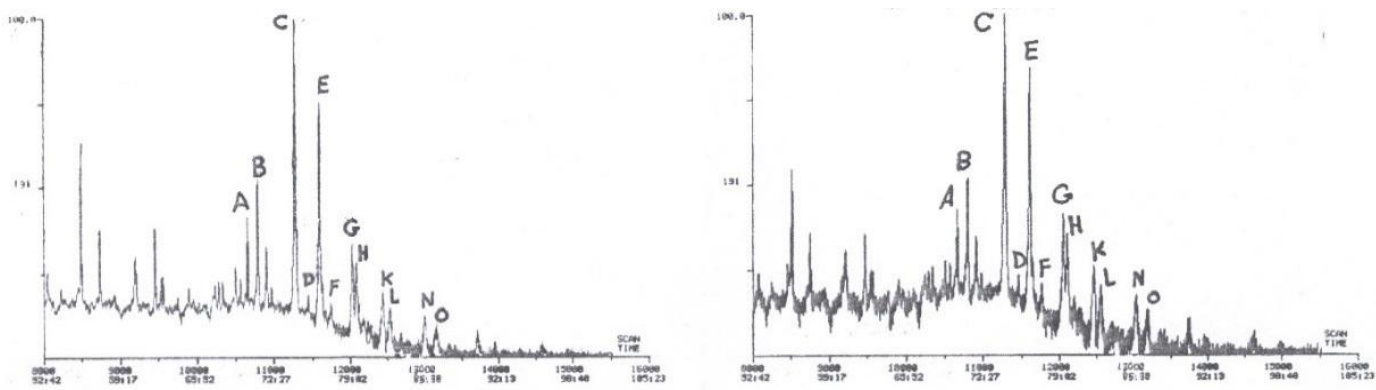

Fig.6 Mass fragment $(\mathrm{m} / \mathrm{z}=191)$ used for identification of specific compounds. 
This transformation includes removal and replacement of methyle group and hydrogen atom in molecular structure of moretane. Moretane/hopan ratio measured for the studied sample range from 0.1 to 0.34 indicating that organic matter is mature to late mature. According to previous works(Seifert and Moldowan 1980, Peters and Moldowan 1993) moretane/hopane ratio of less than 0.15 indicates mature source rock(Table 2, Fig.6). Other biomarkers used to determine thermal maturity and environment of deposition is diasterane/sterane ratio which is measured in mass chromatogram $\mathrm{m} / \mathrm{z}=217$. This ratio for the studied samples range from 1.28 to 1.68(Table 2, Fig.5). Diasteranes are stable forms of regular steranes that their concentration increases with maturation. Recent works show that there are other important factors such as clays and bacteria which are responsible for transformation of unstable steranes to stable diasteranes(McKirdly et al. 1983, Kamali 1995). Measured diasterane/sterane ratio for Golpayegansamples(Fig.5, Table2) indicate that all reactions in transformation of steranes to diasteranes have already reached equilibrium. Therefore maturity of the organic matter is expected to be higher than $0.9 \%$ vitrinite reflectance. An example of extensive biodegradation is clearly represented by a shaly sample. In which all normal alkanes <30 even isoprenoids have been removed by bacteria(Fig.6).

Table2 : Biomarker parameters of source maturity and depositional environment in the cretaceous sediments of golpayegan area using gas chromatography mass spectrometry

\begin{tabular}{|c|c|c|c|c|c|c|c|}
\multirow{2}{*}{\begin{tabular}{c} 
Sample No \\
\cline { 2 - 9 }
\end{tabular}} & Lithology & 1 & 2 & 3 & 4 & 5 & 6 \\
\hline C1 & Thinly bedded black to gray calc. shale & $43: 23: 34$ & 1.68 & 1.11 & 0.15 & 0.42 & 0.95 \\
\hline C4 & Thinly bedded fissile black calc. shale & $40: 23: 37$ & 1.28 & 0.86 & 0.16 & 0.43 & 0.93 \\
\hline C10 & Thinly bedded black to gray calc. shale & $46: 21: 33$ & 1.35 & 0.94 & 0.10 & 0.31 & 0.93 \\
\hline C12 & Fissile black to gray calc. shale & $*$ & $*$ & $*$ & 0.34 & $*$ & $*$ \\
\hline
\end{tabular}

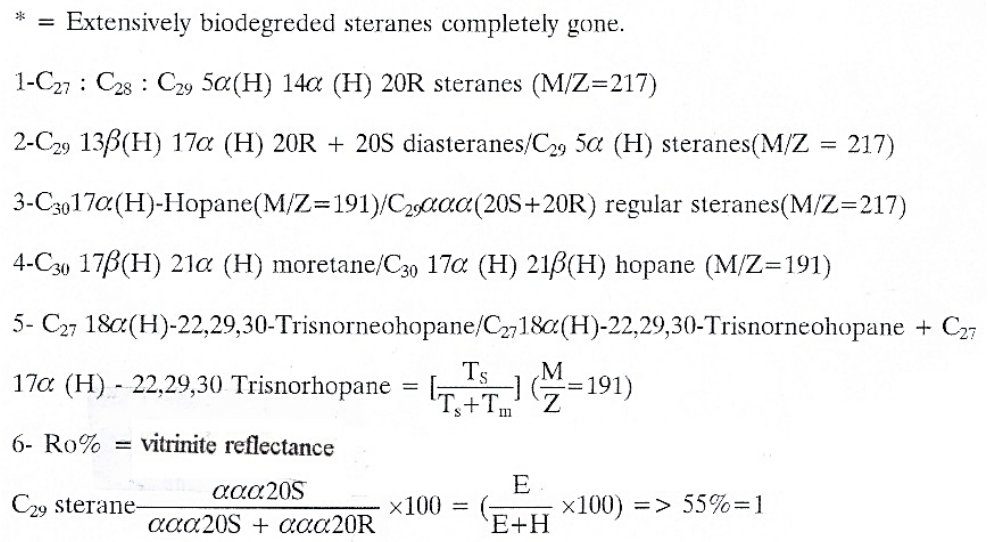

\section{CONCLUSIONS}

This study is the first report of biomarkers present in cretaceous shales and carbonaceous shales, from Golpayegan area that were subjected to gas chromatography and advanced gas chromatography - mass spectrometry. Analysis and investigation of biological markers provided significant information regarding origin, maturity and depositional enviroment of organic matter. Characteristic features of biomarkers of the studied samples include low $\mathrm{pr} / \mathrm{ph}(=1$ or less $)$ ratios and relatively high hopane/sterane ratios which suggest organic matter formed under anoxic and suboxic conditions. High hopane/sterane ratio also suggests bacterial input and bacterial reworking during early diagensis on pure kerogen. Maturity of these sediments using $20 \mathrm{~s} / 20 \mathrm{~s}+20 \mathrm{r}$ ratio in c29 sterane is expected to be over $0.9 \%$ vitrinite reflectance. Therefore from the maturity point of view these rocks have already reached mature stage and are propably at the final of oil window or initial stages of gas window.

\section{ACKNOWLEDGEMENTS}

The authors acknowledge research institute of petroleum industry especially head and staff of geochemistry research group for their kind co-operation and providing research facilities. Our special thanks are due to professor aminsobhani(Head of Department of Geology) and responsible authorities of Islamic Azad University especially South Tehran unit. 


\section{REFRENCES}

[1] Darvishzadeh, a, 1992; geology of iran, neda publication, p.193,561,562.

[2] Grantham,p.j., 1986; the occurrence of unusual c27 and c29 sterancpredominances in two types of oman crude oil, organic geochemistry, pp.9,1-10

[3] Huang, w.and meinschein,w.g.,1976; sterols as source indicators of organic materials in sediment. Geochim. Etcosmochim. Acta 40, pp.323-330.

[4] Kamali,m.r.,1995; sedimentology and petroleum geochemistry of the ouldburra formation, eastern officer basin, Australia, phd.thesis,university of Adelaide(unpublished 359p.)

[5] Mckird,d.m.,aldride,a.k., and ypma,p.j.m,1983; a geochemical comparison of some crude oils from preordovician carbonate rocks. In:bjoroy,m.et al.(eds.), advances in organic geochemistry 1981, wiley,new York,pp.99-107. 